\title{
Major Obstacles And Relationship Among Barriers In Implementing Lean Manufacturing In Indian Industries
}

\author{
AK Singh, Dr MP Singh, \\ Department of Mechanical Engineering Jagannath University,Jaipur
}

\begin{abstract}
Lean philosophy has an important role to play in today's competitive globalised market which is mainly governed by fickle requirement of market, rapid change and advancement in technology, quality, profit, cost reduction and higher expectations of customer. As world has witnessed that implementation of lean concepts in industries has resulted into enhanced productivity, better quality, higher profit, better customer satisfaction, sense of achievement in employees, better employee and employer relation, sense of belonging towards their work. In spite of these advantages lean philosophy has not caught the attention and imagination of top management in all kinds of industries for e.g. SMEs, service industries, system engineering and product development. The main reason of non-implementation of lean concepts can be attributed to various obstacles or barriers being faced by industries. Earlier research indicates that few of the barriers are known to the environment and attempts have also been made by researchers and experts in lean philosophy to establish a relationship between these barriers. In this paper the aim is the correct identification and confirmation of barriers of lean implementation in present scenario and establishing a relationship between them. It is also important to come out with the strategies to overcome the identified obstacles faced by industries in implementing lean philosophy. The approaches in this paper used are firstly in-depth knowledge of subject inanalysis by literature review, secondly by means of a comprehensive questionnaire circulated to various industries to collect the qualitative data, and lastly to validate the data and to derive the inferences.
\end{abstract}

\section{Introduction}

Lean manufacturing is a systematic way of finding all kinds of wastes (mudas) and then eliminating them by using lean principles and tools in order to improve the efficiency and effectiveness of an industry. Taiichi Ohno [1] invented this concept with the introduction of elimination of muda (waste) and introduced this concept in Toyota company and concept is also known as Toyota Production System(TPS).Lean manufacturing is based on three famous M's [1] muda, mura and muri. These three terms are Japanese terms, muda means waste, mura means inconsistency and muri means unreasonableness. In lean manufacturing the main emphasis is on identification and elimination of all kinds of waste and waste can be attributed to all the activities which cost but do not add any value to the product. Seven types of identified mudas [1] which need to be eliminated are as under:-

Over production.It means that items are being produced more than what is required keeping the demands into consideration.

Waiting.Waiting for machine, material or any inputs come under the ambit of waste and results into loss of productive time.

Unnecessary transport.Unnecessary movement of material, work-in-progress inventory and lack of transport results into loss of productivity.

Excess inventory.Excess inventory will lead to losses and will not give the clear picture of reality in terms of supply chain management.

Unnecessary motion. Any motion that does not add value is considered as unnecessary motion.

Defects. If any defect occurs while manufacturing a product then repairs will cause additional cost.

Over processing. If worker carries out operation more than what is required then it will be a waste of effort.

A place for everything and everything in its place is the concept of $5 \mathrm{~S}$ and it entails the following:-

- Seiri (sorting)

- Seiton ( organise)

- Seison (clean)

- Seiketsu (standardization)

- Shitsuke (discipline)

- The five principles $[2,3]$ of lean implementation which needs to be employed are as under:-

- Define value as perceived by the customer.

- Identification of value stream 
- Flow

- Pull

- Perfection

Implementation of lean manufacturing has its advantages [8] and reductions of all kinds of waste takes place due to implementation of it and consequently productivity of industry increases. However, industry faces lots of resistance in implementing and these barriers need to be identified. The correct identification and confirmation of barriers of lean implementation in present scenario and establishing a relationship between them will help in devising the strategies to overcome the identified obstacles faced by industries in implementing lean philosophy. A comprehensive questionnaire has been prepared covering most of the lean practices aspects to obtain the requisite data with an aim to circulate it to various industries to collect the data. The strategies to overcome the barriers of implementation of lean manufacturing will be crucial for the industries for effective and efficient implementation of lean philosophy.

\section{Literature Review}

A comprehensive literature review was carried out and major contributors along with their area of work are enumerated below:-

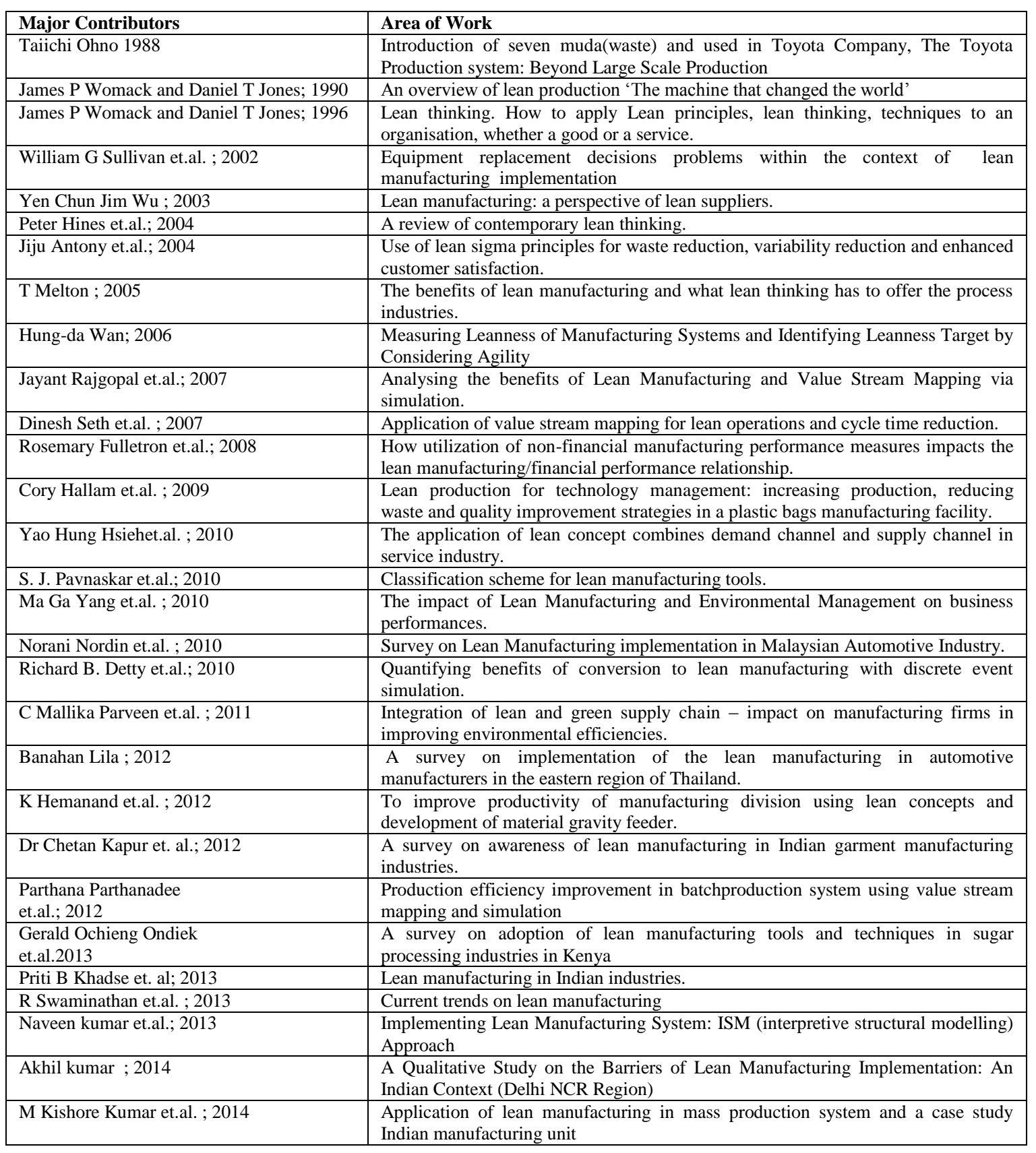


Major Obstacles And Relationship Among Barriers In Implementing Lean Manufacturing In Indian..

\begin{tabular}{|l|l|}
\hline Sahil Dhankar et. al.; 2014 & $\begin{array}{l}\text { Leanness of Indian industries as an objective to find out the lean status of Indian } \\
\text { industries. }\end{array}$ \\
\hline Natasa Vujica Herzog et.al.; 2014 & The instruments for measuring the degree of lean implementation in manufacturing. \\
\hline Jose Dinis-Carvalho et.al.; 2014 & $\begin{array}{l}\text { Management of operations, production planning and control by using waste } \\
\text { identification diagrams. }\end{array}$ \\
\hline William Faulankar et.al.;2014 & $\begin{array}{l}\text { Methodology to visualize and assess manufacturing sustainability performance by } \\
\text { lean manufacturing }\end{array}$ \\
\hline Pardeep Gupta et.al. ; 2015 & $\begin{array}{l}\text { Study of Success Factors of TPM Implementation in Indian Industry towards } \\
\text { Operational Excellence. }\end{array}$ \\
\hline Geir Ringen et.al. ; 2015 & $\begin{array}{l}\text { Implementation of lean practices in knowledge based development practices in } \\
\text { Systems Engineering Companies. }\end{array}$ \\
\hline Abdul Talib Bon et.al. ; 2015 & $\begin{array}{l}\text { Implementation of Lean Manufacturing for Productivity Improvement in Malaysia. } \\
\text { To improve the productivity of a packaging line using lean manufacturing tools and } \\
\text { simulation }\end{array}$ \\
\hline
\end{tabular}

\section{Research Methodology}

Based on literature review and having consulted industry professionals and experts on the subject, a questionnaire was formulated which is a set of questions about the important and critical aspects of lean manufacturing. The questionnaire was divided into various heads giving out the details about organization, experience with lean manufacturing, implementation of lean tools, barriers of lean manufacturing and miscellaneous issues. Industries from various fields were selected for circulating the questionnaire in order to collect the data. Industries wereselected mainly from manufacturing, automobile, garment \& textiles and food industries.

The questionnaire has been designed to get the information about barriers in implementing the lean manufacturing as well as relation among the barriers. To derive the inferences, the questionnaire was structured and designed to rate the questions on the basis of a five point Likert Scale, wherein, ' 1 ' to be assigned for very low, '2' for low, ' 3 ' for moderate, ' 4 ' for high and ' 5 ' for very high.

Cronbach's alpha has been used as a tool to measure the internal consistency and validity of data by using MATLAB software. A minimum value of 0.7 is considered as data to be reliable. Reliability and validity test was carried out by using Cronbach's Alpha for all the parameters and value was found to be more than 0.7. Based on which it can be inferred that data is reliable.

\section{Results}

The questionnaire was circulated to various industries and a number of responses were received. On the basis of responses received from the participants the inferences and conclusion have been drawn.

The use of major lean tools was also assessed through questionnaire. Based on the responses received it has been observed that kaizen is being used extensively in automobile industries followed by 5 S, JIT, Kanban and VSM.For the successful implementation of lean manufacturing it is very essential to understand the forces which resist the implementation and thus acts as a barriers or obstacles. It is evident that barriers do not operate in isolation or independently but affect along with otherdependent barriers. Thus it can be derived that there is a relationship among different barriers. Therefore, it is essential to know about the interlink between various obstacles.Based on the feedback received from the various industries the various types of obstacles have been mapped and are listed below in order of their difficulty level from highest to lowest.

\begin{tabular}{|l|l|}
\hline Obstacles & Ranking \\
\hline Market Volatility & 1 \\
\hline Industry layout & 2 \\
\hline Resistance to change from current model & 3 \\
\hline Cost factor & 4 \\
\hline Product variety & 5 \\
\hline Sustainability & 6 \\
\hline Technological advancement & 7 \\
\hline Process to be changed & 8 \\
\hline Lack of willingness at top level management & 9 \\
\hline Lack of willingness at middle level management & 10 \\
\hline Lack of technological infrastructure to incorporate changes & 11 \\
\hline Fear of failure & 12 \\
\hline Lack of trained manpower & 13 \\
\hline Additional training required & 14 \\
\hline Lack of planning and vision & 15 \\
\hline Lack of willingness at lower level management & 16 \\
\hline
\end{tabular}


Major Obstacles And Relationship Among Barriers In Implementing Lean Manufacturing In Indian..

\begin{tabular}{|l|l|}
\hline Lack of clarity on lean philosophy & 17 \\
\hline Conflict With ERP & 18 \\
\hline Supplier support & 19 \\
\hline Willingness of supplier & 20 \\
\hline Conflict with other initiatives & 21 \\
\hline Creation of multi-functional teams & 22 \\
\hline Lack of time & 23 \\
\hline
\end{tabular}

Table 1

It can be inferred from the above table 1 that few of the barriers offer maximum resistance and are explained below:-

Market Volatility. Now-a-days market volatility playsa vital role and has an adverse effect on implementing lean manufacturing.

Industry Layout.Changing of industry layout will involve cost. Thus industries resist the idea of converting into a lean manufacturing one.

Resistance to change. It is a human tendency to resist the change. Industries find it extremely difficult to overcome this barrier.

Cost factor. Implementation of lean manufacturing concepts will initially require some investment and which discourages the top management in implementing it.

Product Variety With the rapid change in technology and constant demand of varied product have compelled the designer and manufacturer to change the product design and specifications.

Sustainability. Sustainability has become a major concern due to change in product variety, market volatility and technological advancement. This concern is driving away the industries from implementing lean manufacturing.

Responses on questions were received from different industries. Mean and standard deviation of all the questions were calculated so as to draw the inference for various barriers and same have been reflected in fig 1 .

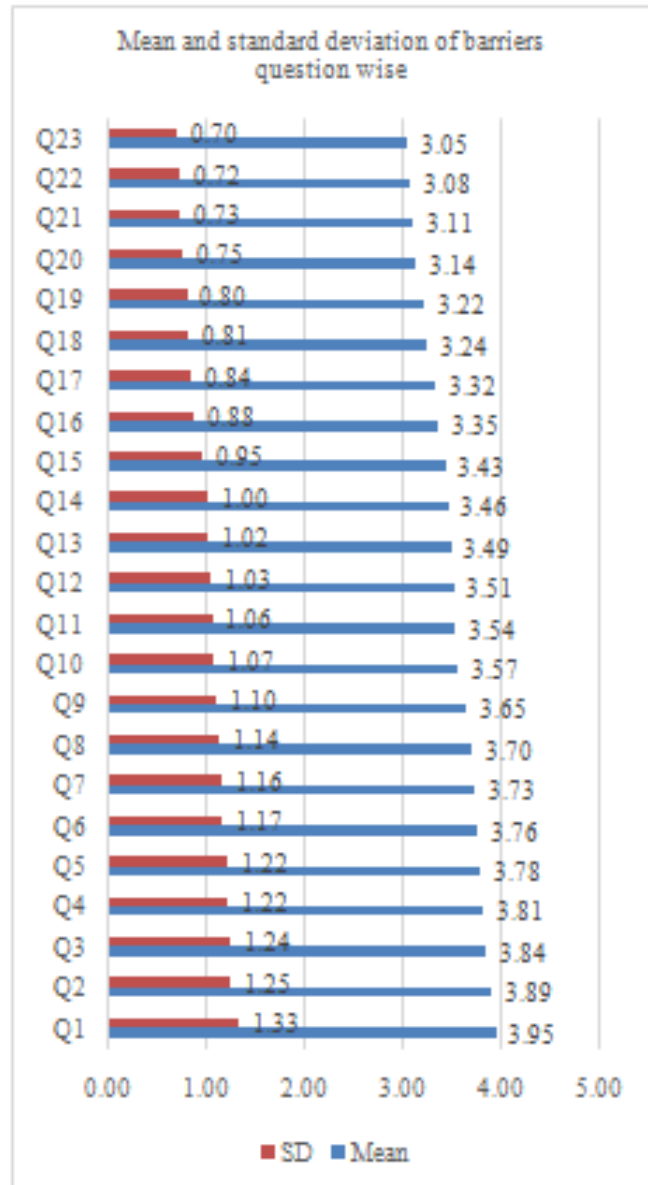

Fig 1 
Mean and standard deviation of response of companies have been calculated and reflected in fig 2.

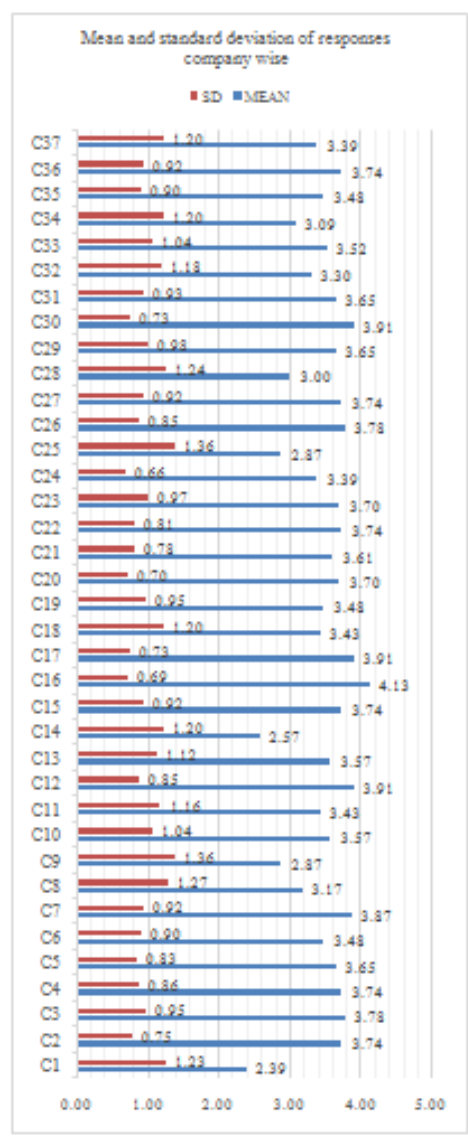

Fig 2

Value of Cronbach's alpha has been calculated for all the questions to measure the internal consistency and validity of data. It is evident from the graph depicted at fig 3 that Cronbach's Alpha value is more than 0.7, which validates the internal consistency of data and data in analysis can be considered as reliable.

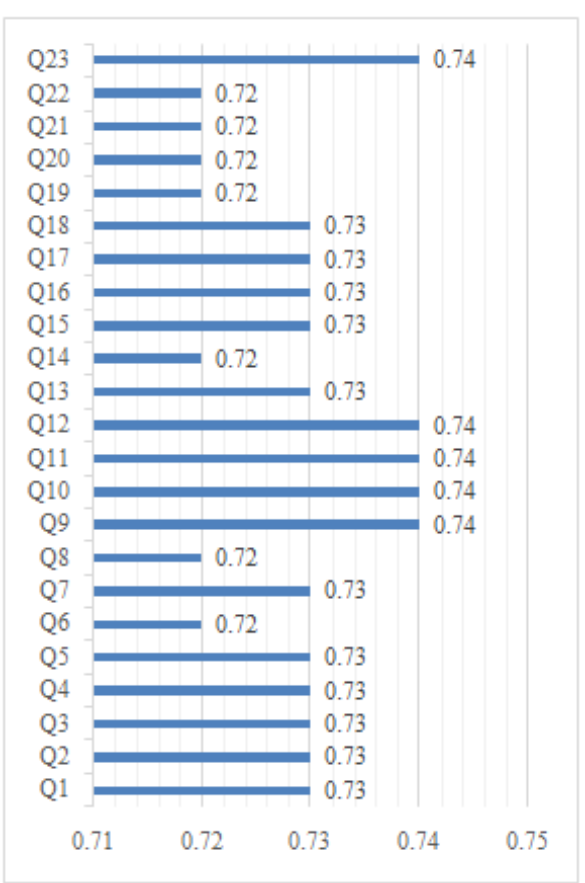

Fig 3 
Relationship among different barriers A relationship exists among the following barriers and as follows:-

- Market volatility, product variety, sustainability and technological advancement.

Table 2

\begin{tabular}{|c|c|c|c|c|c|c|c|c|c|c|c|c|}
\hline Barriers & 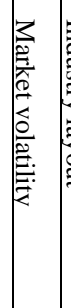 & 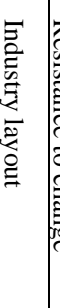 & 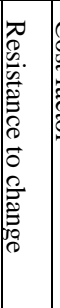 & 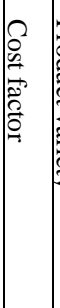 & 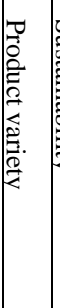 & 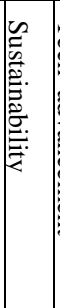 & 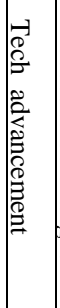 & 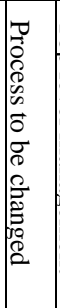 & 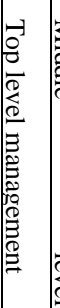 & 产 & & 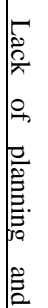 \\
\hline Market volatility & - & - & - & $\mathrm{Y}$ & $\mathrm{Y}$ & $\mathrm{Y}$ & $\mathrm{Y}$ & $\mathrm{Y}$ & $\mathrm{Y}$ & $\mathrm{Y}$ & $\mathrm{Y}$ & $\mathrm{Y}$ \\
\hline Industry layout & - & - & - & $\mathrm{Y}$ & $\mathrm{Y}$ & $\mathrm{Y}$ & $\mathrm{Y}$ & $\mathrm{Y}$ & $\mathrm{Y}$ & $\mathrm{Y}$ & - & $\mathrm{Y}$ \\
\hline Resistance to change & - & - & - & - & - & - & - & $\mathrm{Y}$ & $\mathrm{Y}$ & $\bar{Y}$ & $\mathrm{Y}$ & - \\
\hline Cost factor & $\mathrm{Y}$ & $\mathrm{Y}$ & - & - & $\mathrm{Y}$ & $\mathrm{Y}$ & $\mathrm{Y}$ & $\mathrm{Y}$ & $\mathrm{Y}$ & - & - & - \\
\hline Product variety & $\mathrm{Y}$ & $\mathrm{Y}$ & - & $\mathrm{Y}$ & - & $\mathrm{Y}$ & $\mathrm{Y}$ & $\mathrm{Y}$ & - & - & - & - \\
\hline Sustainability & $\mathrm{Y}$ & $\mathrm{Y}$ & - & $\mathrm{Y}$ & $\mathrm{Y}$ & - & $\mathrm{Y}$ & - & $\mathrm{Y}$ & - & - & $\mathrm{Y}$ \\
\hline Tech advancement & $\mathrm{Y}$ & $\mathrm{Y}$ & - & $\mathrm{Y}$ & $\mathrm{Y}$ & $\mathrm{Y}$ & - & $\mathrm{Y}$ & $\mathrm{Y}$ & $\mathrm{Y}$ & - & - \\
\hline Process to be changed & $\mathrm{Y}$ & $\mathrm{Y}$ & $\mathrm{Y}$ & $\mathrm{Y}$ & $\mathrm{Y}$ & - & $\mathrm{Y}$ & - & - & $\mathrm{Y}$ & - & $\mathrm{Y}$ \\
\hline Top level management & $\mathrm{Y}$ & $\mathrm{Y}$ & $\mathrm{Y}$ & $\mathrm{Y}$ & - & $\mathrm{Y}$ & $\mathrm{Y}$ & - & - & $\mathrm{Y}$ & $\mathrm{Y}$ & $\mathrm{Y}$ \\
\hline Middle level management & $\mathrm{Y}$ & $\mathrm{Y}$ & $\mathrm{Y}$ & - & - & - & $\mathrm{Y}$ & $\mathrm{Y}$ & $\mathrm{Y}$ & - & $\mathrm{Y}$ & - \\
\hline Fear of failure & $\mathrm{Y}$ & - & $\mathrm{Y}$ & - & - & - & - & - & $\mathrm{Y}$ & $\mathrm{Y}$ & - & - \\
\hline Lack of planning and vision & $\mathrm{Y}$ & $\mathrm{Y}$ & - & - & - & $\mathrm{Y}$ & - & $\mathrm{Y}$ & $\mathrm{Y}$ & - & - & - \\
\hline Lack of tech infrastructure & $\mathrm{Y}$ & $\mathrm{Y}$ & - & $\mathrm{Y}$ & $\mathrm{Y}$ & $\mathrm{Y}$ & $\mathrm{Y}$ & $\mathrm{Y}$ & $\mathrm{Y}$ & - & - & - \\
\hline Lack of trained manpower & - & - & $\mathrm{Y}$ & $\mathrm{Y}$ & $\mathrm{Y}$ & $\mathrm{Y}$ & $\mathrm{Y}$ & $\mathrm{Y}$ & - & $\mathrm{Y}$ & $\mathrm{Y}$ & - \\
\hline Additional training required & - & $\mathrm{Y}$ & - & $\mathrm{Y}$ & $\mathrm{Y}$ & - & $\mathrm{Y}$ & $\mathrm{Y}$ & - & $\mathrm{Y}$ & - & $\mathrm{Y}$ \\
\hline Lower level management & - & - & $\mathrm{Y}$ & - & - & - & - & - & $\mathrm{Y}$ & $\mathrm{Y}$ & $\mathrm{Y}$ & - \\
\hline Lack of clarity on lean & - & $\mathrm{Y}$ & $\mathrm{Y}$ & $\mathrm{Y}$ & - & $\mathrm{Y}$ & $\mathrm{Y}$ & $\mathrm{Y}$ & $\mathrm{Y}$ & $\bar{Y}$ & $\mathrm{Y}$ & $\mathrm{Y}$ \\
\hline Conflict With ERP & - & - & $\mathrm{Y}$ & $\mathrm{Y}$ & $\mathrm{Y}$ & - & - & - & - & $\mathrm{Y}$ & - & - \\
\hline Supplier support & - & - & $\mathrm{Y}$ & $\mathrm{Y}$ & $\mathrm{Y}$ & - & - & - & - & $\mathrm{Y}$ & $\mathrm{Y}$ & - \\
\hline Willingness of supplier & - & - & $\mathrm{Y}$ & $\mathrm{Y}$ & $\mathrm{Y}$ & - & - & - & - & $\mathrm{Y}$ & $\mathrm{Y}$ & - \\
\hline Conflict to other initiatives & - & - & $\mathrm{Y}$ & $\mathrm{Y}$ & - & - & $\mathrm{Y}$ & - & $\mathrm{Y}$ & $\mathrm{Y}$ & $\mathrm{Y}$ & - \\
\hline Multi-functional teams & - & $\mathrm{Y}$ & $\mathrm{Y}$ & $\mathrm{Y}$ & $\mathrm{Y}$ & $\mathrm{Y}$ & $\mathrm{Y}$ & $\mathrm{Y}$ & - & $\mathrm{Y}$ & $\mathrm{Y}$ & - \\
\hline Lack of time & - & - & - & - & - & - & - & - & $\mathrm{Y}$ & $\mathrm{Y}$ & - & $\mathrm{Y}$ \\
\hline
\end{tabular}

- $\quad$ Lack of planning and vision, top level management and middle level management.

- Industry layout, training, processes to be changed, cost factor and technological infrastructure.

- Lack of clarity on lean philosophy, resistance to change and fear of failure.

- Conflict among ERP and other initiatives.

- Relationship among different is shown below in the table and ' $\mathrm{Y}$ ' in the table indicates 'yes' for a relationship between two barriers.

\section{Conclusion}

It is evident from the findings that market volatility, industry layout, resistance to change, cost factor, product variety and sustainability are the key barriers. A synergic strategy needs to be devised to overcome these barriers. A dedicated commitment from top level management and all employees is necessary in implementing lean manufacturing concepts. It cannot be implemented in isolation or independently. All will have to participate willingly and thus awareness about lean manufacturing is extremely critical. Training must be imparted to the employees The relationship among different barriers needs to be clearly explained to all decision makers so as to have synergetic attempts in overcoming the barriers.

\section{Reference}

[1]. Taiichi Ohno (1988) The Toyoto Production System : Beyond large scale production

[2]. Womack, James P., and Daniel T.Jones (1990), The Machine That Changed The World.

[3]. Womack, James P., and Daniel T.Jones (2003), Lean Thinking.

[4]. William G Sullivan et.al. (2002) Equipment replacement decisions problems within the context of lean manufacturing implementation

[5]. Yen Chun Jim Wu (2003) Lean manufacturing: A perspective of lean suppliers.

[6]. Peter Hines et.al. ( 2004) : A review of contemporary lean thinking.

[7]. Jiju Antony et.al. (2004) : Use of lean sigma principles for waste reduction, variability reduction and enhanced customer satisfaction.

[8]. T Melton (2005) : The benefits of lean manufacturing and what lean thinking has to offer the process industries.

[9]. Hung-da Wan (2006) : Measuring Leanness of Manufacturing Systems and Identifying Leanness Target by Considering Agility.

[10]. Jayant Rajgopal et.al (2007) : Analyzing the benefits of Lean Manufacturing and Value Stream Mapping via simulation. 
[11]. Dinesh Seth et.al. (2007) : Application of value stream mapping for lean operations and cycle time reduction.

[12]. Rosemary Fulletron et.al. (2008) : How utilization of non-financial manufacturing performance measures impacts the lean manufacturing/financial performance relationship.

[13]. Cory Hallam et.al. (2009) : Lean production for technology management :increasing production, reducing waste and quality improvement strategies in a plastic bags manufacturing facility.

[14]. Yao Hung Hsiehet.al. (2010) : The application of lean concept combines demand channel and supply channel in service industry.

[15]. S. J. Pavnaskar et.al. (2010) : Classification scheme for lean manufacturing tools.

[16]. Ma Ga Yang et.al. (2010) : The impact of Lean Manufacturing and Environmental Management on business performances.

[17]. Norani Nordin et.al. (2010) : Survey on Lean Manufacturing implementation in Malaysian Automotive Industry.

[18]. Richard B. Detty et.al. (2010) : Quantifying benefits of conversion to lean manufacturing with discrete event simulation.

[19]. C Mallika Parveen et.al. (2011) : Integration of lean and green supply chain - impact on manufacturing firms in improving environmental efficiencies.

[20]. Banahan Lila (2012) : A survey on implementation of the lean manufacturing in automotive manufacturers in the eastern region of Thailand.

[21]. K Hemanand et.al. (2012) : To improve productivity of manufacturing division using lean concepts and development of material gravity feeder.

[22]. Dr Chetan Kapur et. al. (2012) : A survey on awareness of lean manufacturing in Indian garment manufacturing industries.

[23]. Parthana Parthanadee et.al. (2012) : Production efficiency improvement in batch production system using value stream mapping and simulation.

[24]. Gerald Ochieng Ondiek et.al. (2013) : A survey on adoption of lean manufacturing tools and techniques in sugar processing industries in Kenya.

[25]. Priti B Khadse et. al. (2013) : Lean manufacturing in Indian industries.

[26]. R Swaminathan et.al. (2013) : Current trends on lean manufacturing.

[27]. Naveen kumar et.al. (2013) : Implementing Lean Manufacturing System: ISM (interpretive structural modelling) Approach.

[28]. Akhil kumar (2014) : A Qualitative Study on the Barriers of Lean Manufacturing Implementation: An Indian Context (Delhi NCR Region).

[29]. M Kishore Kumar et.al. (2014) : Application of lean manufacturing in mass production system and a case study Indian manufacturing unit.

[30]. Sahil Dhankar et. al. (2014) : Leanness of Indian industries as an objective to find out the lean status of Indian industries

[31]. Natasa Vujica Herzog et.al. (2014) : The instruments for measuring the degree of lean implementation in manufacturing.

[32]. Jose Dinis-Carvalho et.al. (2014) : Management of operations, production planning and control by using waste identification diagrams.

[33]. William Faulankar et.al. (2014) : Methodology to visualize and assess manufacturing sustainability performance by lean manufacturing.

[34]. Pardeep Gupta et.al. (2015) : Study of Success Factors of TPM Implementation in Indian Industry towards Operational Excellence.

[35]. Geir Ringen et.al. (2015) : Implementation of lean practices in knowledge based development practices in Systems Engineering Companies.

[36]. Abdul Talib Bon et.al. (2015) : Implementation of Lean Manufacturing for Productivity Improvement in Malaysia.

[37]. Ana Luisa Ramos et.al. (2015) : To improve the productivity of a packaging line using lean manufacturing tools and simulation. 